\title{
Geology of the
}

Grosvenor Quadrangle

Brown and Coleman

Counties, Texas

GEOLOGICAL SURVEY BULLETIN 1096 -A

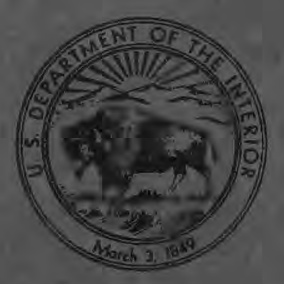




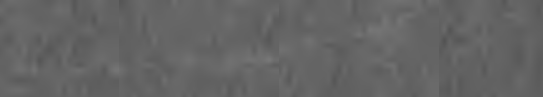

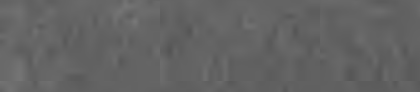

(1) $1:-1$

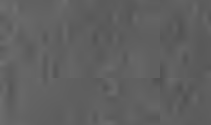

$7 x^{2}-x^{2}+x^{2}$

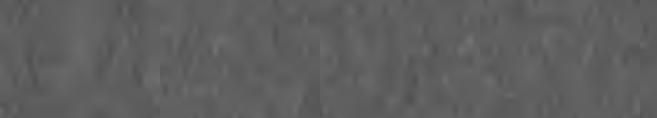

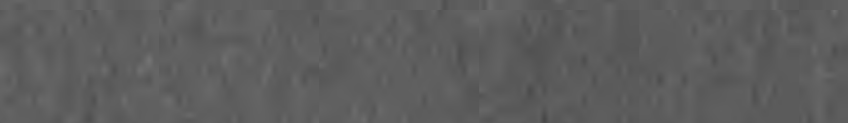

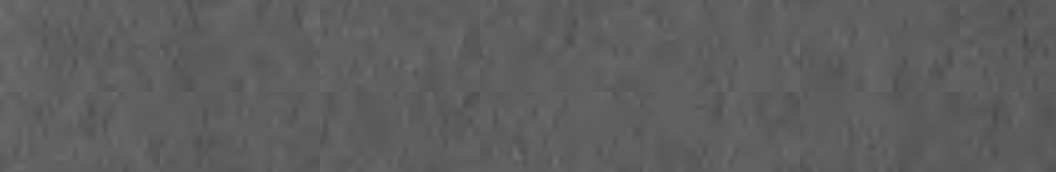

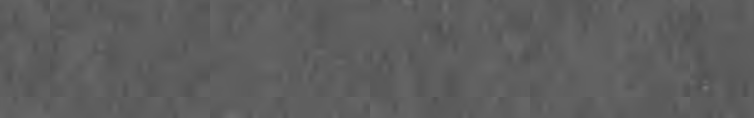

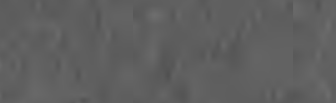

2.11

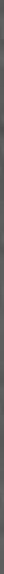

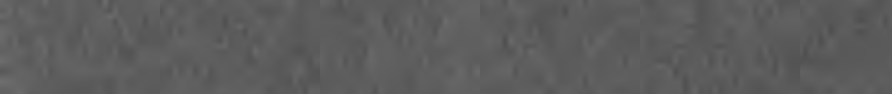

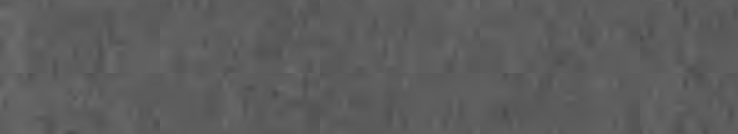

Y

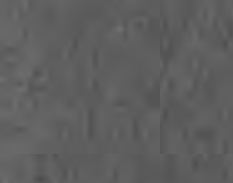

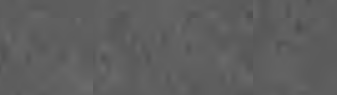

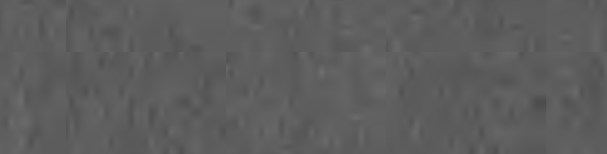

1.3.

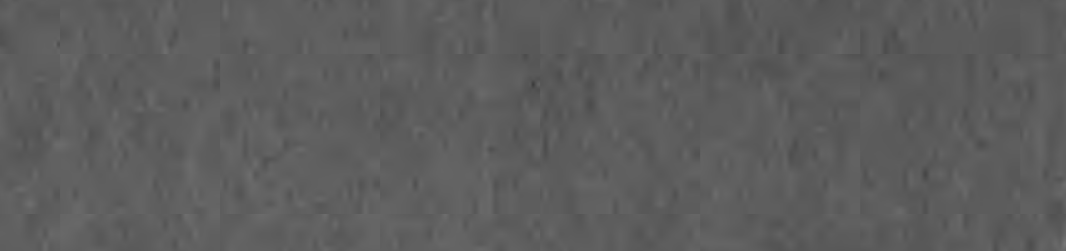

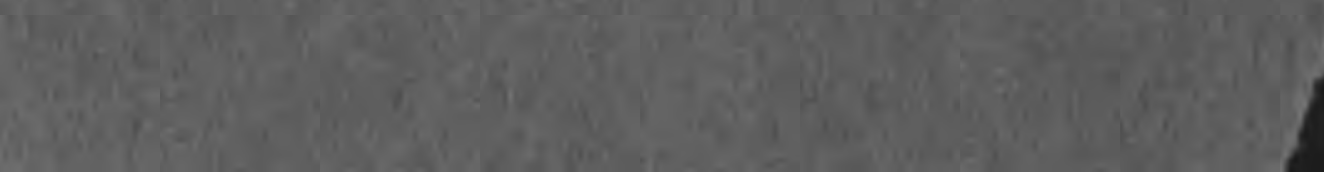




\section{Geology of the}

\section{Grosvenor Quadrangle}

\section{Brown and Coleman}

\section{Counties, Texas}

By ROBERT T. TERRIERE

PENNSYLVANIAN AND LOWER PERMIAN STRATIGRAPHY BETWEEN THE BRAZOS AND COLORADO RIVERS, NORTH-CENTRAL TEXAS

GE OLOGICAL S U R VEY B ULLETIN 1096-A

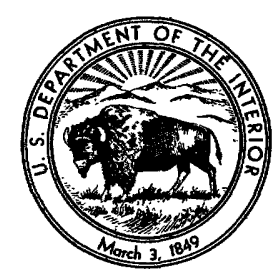




\section{UNITED STATES DEPARTMENT OF THE INTERIOR}

FRED A. SEATON, Secretary

\section{GEOLOGIGAL SURVEY}

Thomas B. Nolan, Director

For sale by the Superintendent of Documents, U.S. Government Printing Office Washington 25, D.C. 


\section{CONTENTS}

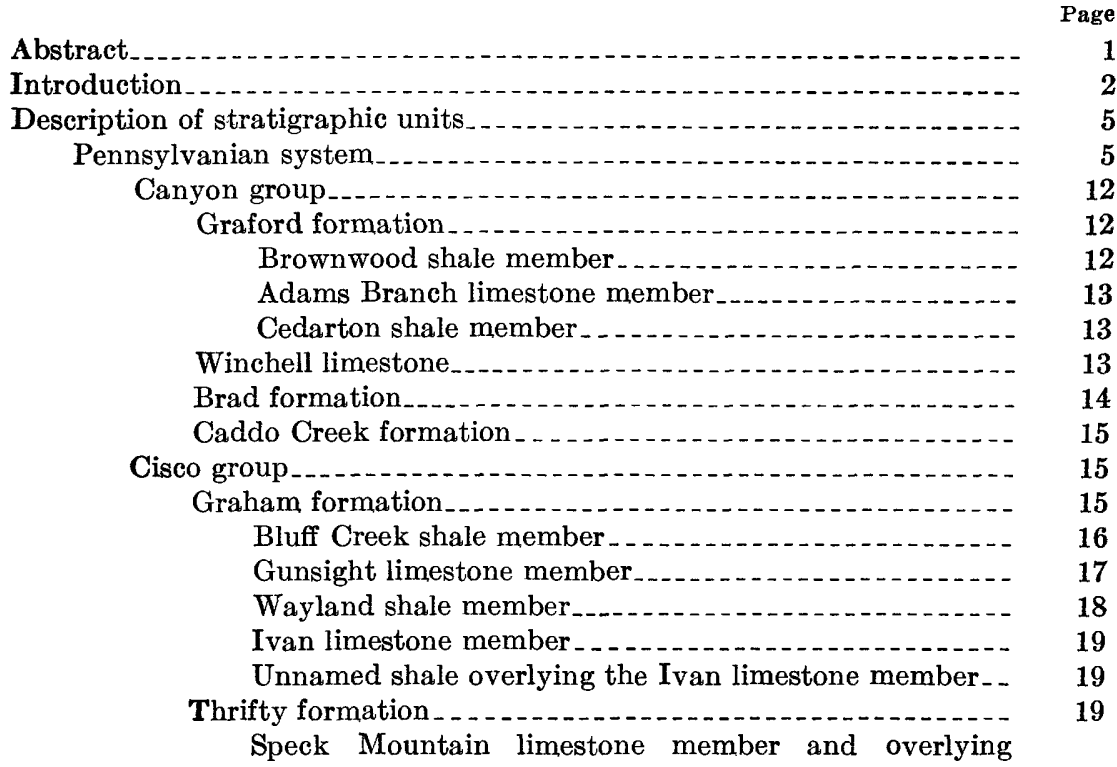

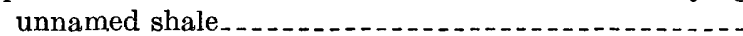

Breckenridge limestone member and overlying unnamed shale.

Permian system.

Wichita group........... 21

Pueblo formation . . .

Waldrip shale member. .............. 22

Saddle Creek limestone member.............. 22

Camp Creek shale member. . .

Coon Mountain sandstone member. . . . . . . . . 23

Stockwether limestone member................. 24

Salt Creek Bend shale member._._.

Camp Colorado limestone member......... 25

Moran formation........ 26

Watts Creek shale member.

Gouldbusk limestone member.

Santa Anna shale member.

Sedwick limestone member. . . .

Channel deposits .............. 27

Cretaceous system,_... 29

Quaternary system ... 30 
Geologic structure

Oil and gas . .

Descriptions of localities of individual collections of fossils.

Literature cited.............. 34

\section{ILLUSTRATIONS}

[Plates 1-3 are in pocket]

Plate 1. Geologic map of the Grosvenor quadrangle, Texas.

2. Composite stratigraphic section of Pennsylvanian and Permian rocks of the Grosvenor quadrangle, Texas.

3. Cut and fill relationships of sandstone, siltstone, and shale on the east edge of Coon Mountain.

Figure 1. Index map of north-central Texas showing major rock units in relation to the Grosvenor quadrangle.

2. Diagram of Indian Mountain showing stratigraphic relationships of channel-fill sandstones of the upper part of the Thrifty formation and the lower part of the Pueblo formation

3. Diagram showing typical relationships of sedimentary rocks overlying the Breckenridge limestone member of the Thrifty formation in the central part of the Grosvenor quadrangle ..-

4. Diagram showing stratigraphic relationships of channel-fill deposits on Coon Mountain and westward.

5. Diagram along line $B-B^{\prime}$ (pl. 1) showing stratigraphic and topographic relationships of two channel-fill deposits in the Salt Creek Bend shale member of the Pueblo formation..........

6. Diagram along line $A-A^{\prime}$ (pl. 1) showing stratigraphic and topographic relationships between the Camp Colorado limestone member of the Pueblo formation and channel-fill deposits in the overlying Watts Creek shale member of the Moran for-

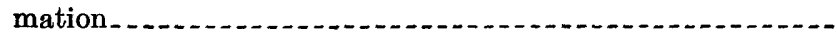

\section{TABLE}

TABLE 1. Distribution of megafossils and ostracodes in collections from formations in the Grosvenor quadrangle, Texas............ 


\title{
PENNSYLVANIAN AND LOWER PERMIAN STRATIGRAPHY BETWEEN THE BRAZOS AND COLORADO RIVERS, NORTH-CENTRAL TEXAS
}

\section{GEOLOGY OF THE GROSVENOR QUADRANGLE, BROWN AND GOLEMAN GOUNTIES, TEXAS}

\author{
By Robert T. TerrIere
}

\begin{abstract}
The Grosvenor quadrangle is underlain by Pennsylvanian and lower Permian sedimentary rocks that dip gently to the west-northwest. Isolated patches of Lower Cretaceous strata, dipping slightly to the southeast, overlap the Pennsylvanian and Permian rocks. Quaternary alluvium and terrace deposits cover older rocks along stream valleys.

The Pennsylvanian rocks include the Canyon and Cisco groups; the Wichita group represents the Permian system. The position of the systemic boundary is believed to be in the Waldrip shale member of the Pueblo formation near the base of the Wichita group but is drawn at the base of the Waldrip for practical purposes.

The Pennsylvanian and Permian rocks consist mainly of gray shale but also contain limestone, siltstone, sandstone, conglomerate, and red shale. Most of the sandstone and conglomerate occupy broad shallow channels cut during Pennsylvanian and early Permian time. Shale and siltstone also fill parts of some channels.

The Canyon group contains thicker limestone units and a larger proportion of limestone than do the Cisco and Wichita groups. Only one channel-fill deposit was found in the Canyon group within the quadrangle, although two other local channels have been reported in nearby areas.

The Cisco and Wichita groups contain many channel deposits. These are especially numerous in the lower part of the Wichita group. Three or more of these channel deposits are superimposed on one another and can be differentiated only by detailed study of their relationship to limestone beds. Within some of these main channels are smaller channels that seem to be the result of local cut and fill.

The Cretaceous rocks of the quadrangle consist of conglomerate, sandstone, siltstone, and shale. Sandstone is the most abundant and in many parts of the area has weathered to a blanket of loose sand.

Quarternary deposits consist of alluvium and scattered patches of terrace gravel along the main streams. The alluvium typically forms low-level terraces that have been incised recently and contain abandoned meanders and ox-
\end{abstract}


bow lakes. Remnants of higher terraces, covered with gravel, are several tens of feet above the present stream levels.

Large amounts of oil and gas have been produced in the Grosvenor quadrangle. Most of the oil and gas produced have come from lenticular sandstone beds in the Canyon group and the underlying Strawn group, but similar beds in the Cisco group produce oil west and north of the quadrangle. These oilproducing sandstones in the Cisco group resemble channel-fill deposits described in this report and appear to be their subsurface equivalents.

\section{INTRODUCTION}

Rocks of Pennsylvanian and earliest Permian age are exposed in central and north-central Texas in a band extending northward and northeastward from the northern edge of the Llano uplift (fig. 1). These beds are of special interest because of their stratigraphic equivalence to rocks producing large amounts of oil and gas in western Texas. In 1950, the U.S. Geological Survey began a study of the Pennsylvanian and lower Permian strata of central and western Texas to determine the lithology, distribution, stratigraphic relationships, and conditions of deposition of these sedimentary rocks. Some of the results of that study have been presented in papers by Stafford, 1959, Burnside, 1959, Myers, Stafford, and Burnside (1956), Eargle (1960), and Myers (in press). This report on the geology of the Grosvenor quadrangle constitutes another in that series, and shows the areal distribution and lithologic character of some of the Pennsylvanian and lower Permian rocks on their outcrop in central Texas (pls. 1 and 2). The paper is part of a dissertation submitted to the Department of Geology, The University of Texas as a partial requirement for the Ph. D. degree.

The mapping of the quadrangle was started in the summer of 1952 and completed during the summers of 1953 and 1954. Philip T. Stafford mapped the northeastern and extreme northern part of the area and furnished the author with considerable stratigraphic data. The mapping was done on air photographs on a scale of $1: 20,000$. Although many of the beds stand out prominently on the photographs, it was necessary to trace most of them carefully in the field to avoid the possibility of serious inaccuracies. This was especially true for the thin limestone beds of the Graham formation of the Cisco group and for beds near channels of Pennsylvanian and Permian age.

The geologic data were transferred from the photographs to a controlled base that had been compiled from the photographs by means of templates and a radial planimetric plotter. The photographs used for the part of the map for Brown County were taken in 1948 and those for Coleman County, in 1938. At some places in the quadrangle, appreciable changes have been made in the culture since the 
photographs were taken; only a few of these changes have been shown on the map.

Several problems of representation were faced in compiling the geology on the map. Narrow inliers of Pennsylvanian and lower Permian rocks in alluvium along stream channels are important outcrops but are too small to be precisely shown at the scale of the map. These inliers have been shown by locally exaggerating their size, and by swinging alluvial contacts around the outcrops in stream channels.

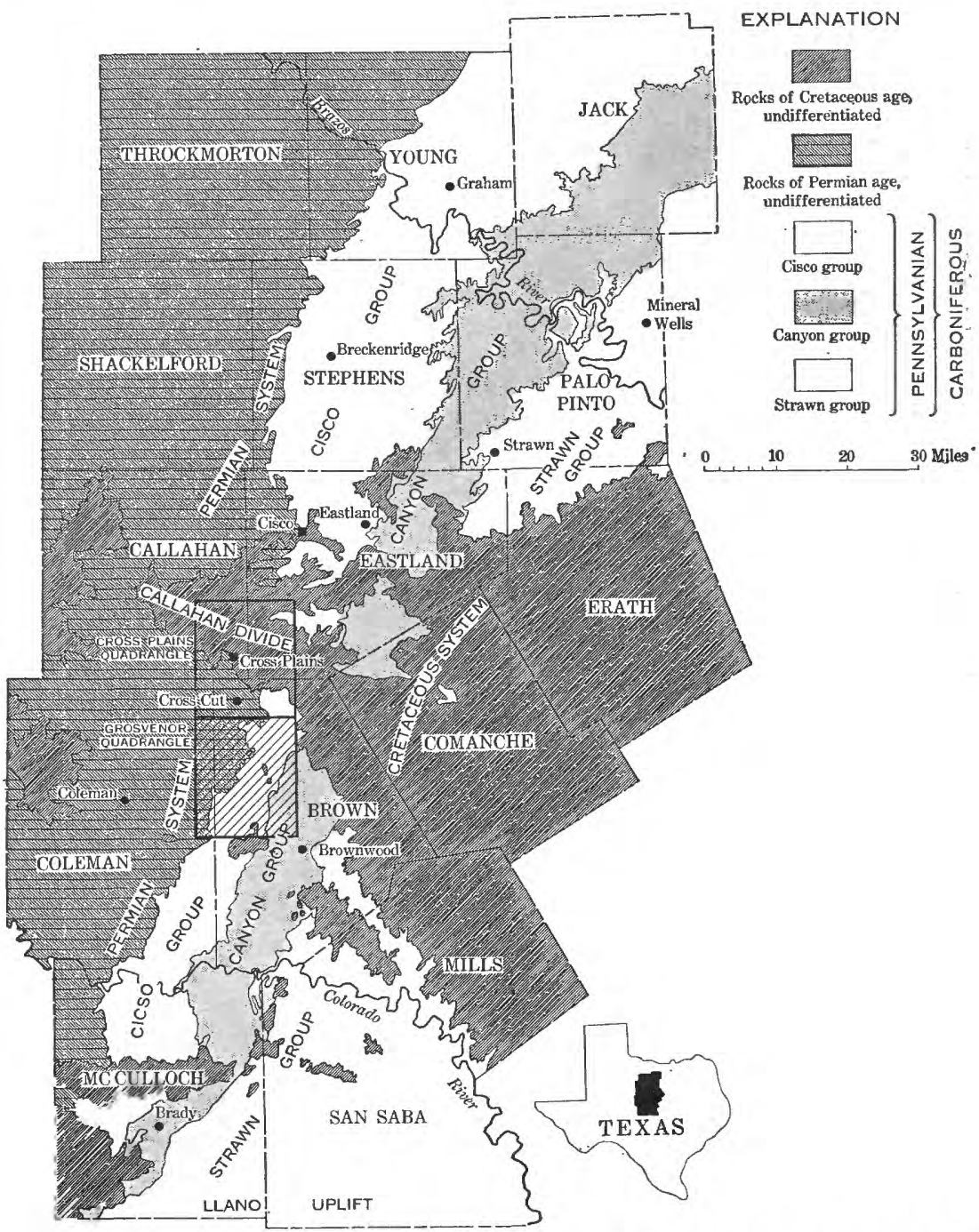

Figure 1.-Index map of north-central Texas showing major rock units In relation to the Grosvenor quadrangle. 
The outcrop extent of Pennsylvanian and Permian channel deposits, and presumed channel deposits, are shown on the map by a dotted pattern. Most of the area shown by this dotted pattern represents deposits filling shallow channels that have locally removed slightly older, traceable beds. The channel-fill deposits consist mostly of sandstone and conglomerate but in some places include siltstone and shale. Where the channeling relationships are not indicated by interruption of otherwise continuous beds, channel-fill sedimentary rocks are difficult to differentiate from rocks in the normal sequence. However, some lenticular sandstone bodies so markedly resemble deposits known to fill channels that they are shown with a dotted pattern even though they may not interrupt traceable beds.

The most easily mapped units are the limestone beds. Although subordinate to the shale in volume, they make excellent marker beds because of their lateral continuity, distinctive faunas and lithologic character, and topographic prominence. The bases of the limestone beds are relatively well exposed on the faces of benches and cuestas, but their tops commonly are concealed by soil or float on the tops of benches or on dip slopes. The tops and bases of the relatively thick limestone units of the Canyon group were mapped separately, but only the bases of the thinner limestone beds of the Cisco and Wichita groups were mapped.

Fossils were collected from localities where they are most abundant. They were studied by Mackenzie Gordon, Jr., Helen Duncan, Ellis Yochelson, and I. G. Sohn. Corals and bryozoans were given preliminary identification by Duncan, primarily to establish general generic relationships. Gastropods were identified as completely as possible by Yochelson. Sohn identified the ostracodes. All other fossils shown in table 1 were identified by Gordon. Fusulinids are not included in table 1 inasmuch as they are reported separately by D. A. Myers (in press) ; the area of Myers' study includes the Grosvenor quadrangle. Descriptions of the localities are given on pages $33-34$.

The fossils are now a part of the U.S. Geological Survey collections in Washington, D.C. Cretaceous fossils were not found in the Grosvenor quadrangle, although slightly younger Cretaceous rocks in adjacent areas are very fossiliferous.

In the description of lithologic units, the Wentworth size classification is followed in using the terms "conglomerate," "sandstone," and "siltstone." The term "shale" is used for rocks of finer average grain size than siltstone, regardless of the presence or absence of lamination or fissility. Limestone is called microcrystalline if it contains relatively small amounts of clastic debris and is composed largely of crystals too small to be distinguished with the naked eye. 
No objective standard is used in describing bedding as thin, medium, or thick. In general, beds less than about 4 inches thick are called thin, those between about 4 inches and 1 foot in thickness are called medium thick, and those about 1 foot thick or thicker are called thick. Limestone units are termed "massive" if the entire thickness consists of a single bed.

The Rock-Color Chart of the National Research Council was used for many of the color designations. Some rock units have several different color shades within the area studied, or even within a single outcrop. The colors of such units are given in terms more general than those given by the color chart.

\section{DESCRIPTION OF STRATIGRAPHIC UNITS}

The Grosvenor quadrangle is underlain by Pennsylvanian and Permian sedimentary rocks that dip gently to the west-northwest. Isolated patches of Lower Cretaceous rocks, dipping slightly to the southeast, overlap the Pennsylvanian and Permian rocks. Quaternary alluvium and terrace gravel cover older rocks along stream valleys. The Pennsylvanian and Permian strata were the principal object of the study and are described in the greatest detail.

\section{PENNSYLVANIAN SYSTEM}

The Pennsylvanian rocks of the quadrangle consist of gray and red shale with subordinate amounts of limestone and sandstone. Much of the sandstone fills broad, shallow channels cut into the shale and limestone. In general, red shale and channel-fill standstone become more abundant upward into the Permian system.

These rocks belong to the Canyon and Cisco groups of Pennsylvanian age. Eargle (1960) discussed the stratigraphy of the Strawn, Canyon, and Cisco groups and the lower part of the Wichita group of Permian age, and revised many of the boundaries and nomenclature of their component formations, members, and beds. His usage is followed in this paper. Rocks younger than the Coon Mountain sandstone member of the Pueblo formation of the Wichita group were not treated by Eargle; the nomenclature of Moore (1949) is used for them.

The exact position of the Pennsylvanian and Permian systemic boundary in central Texas is in doubt. Fusulinid evidence (Moore, 1949) suggests that the Waldrip No. 3 limestone bed of Drake (1893) in the upper part of the Waldrip shale member of the Pueblo formation is of Wolfcamp (Permian) age and that the Chaffin limestone member of the Thrifty formation is Pennsylvanian. Moore states further that the systemic boundary is an obscure disconformity. 


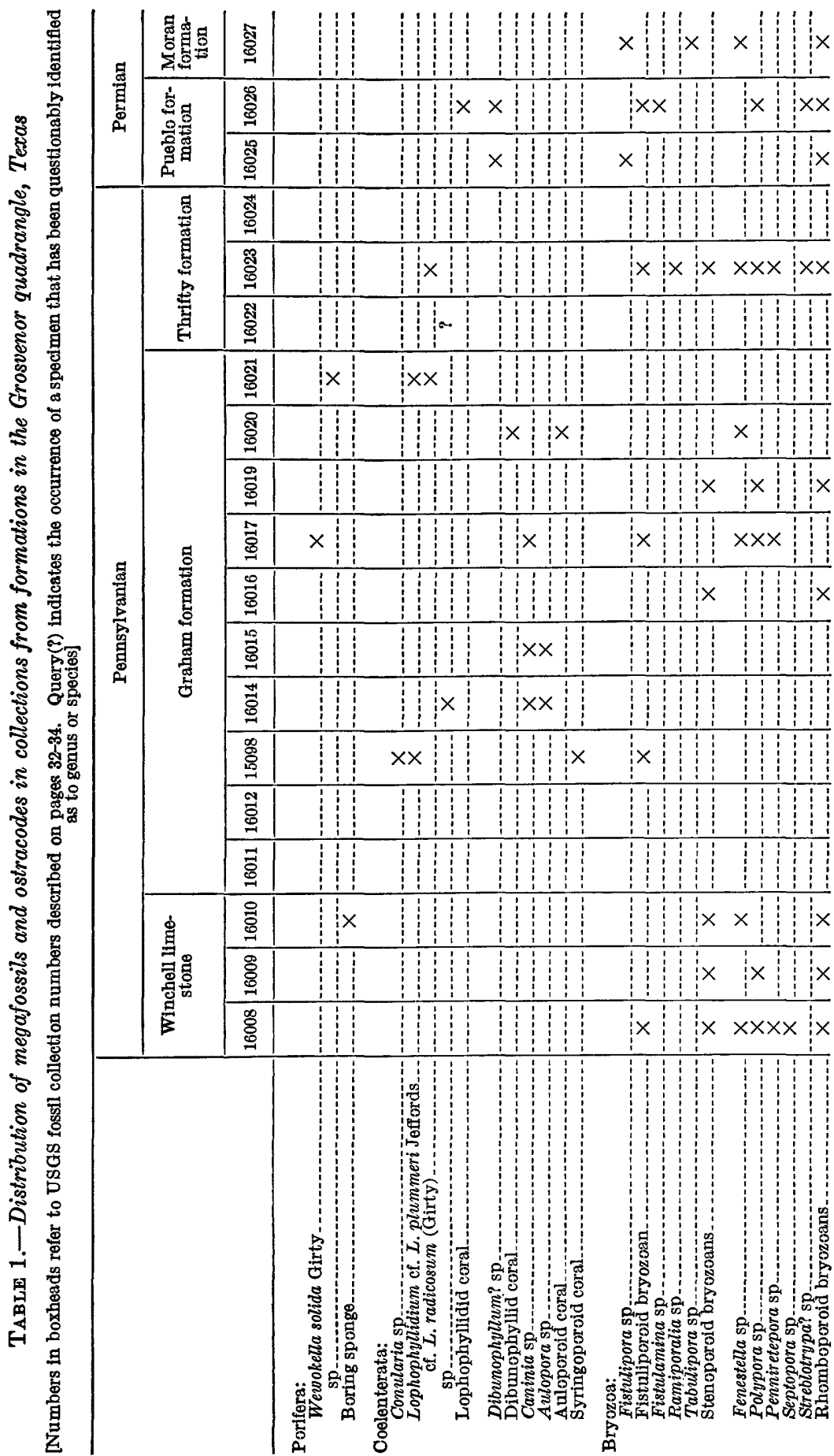




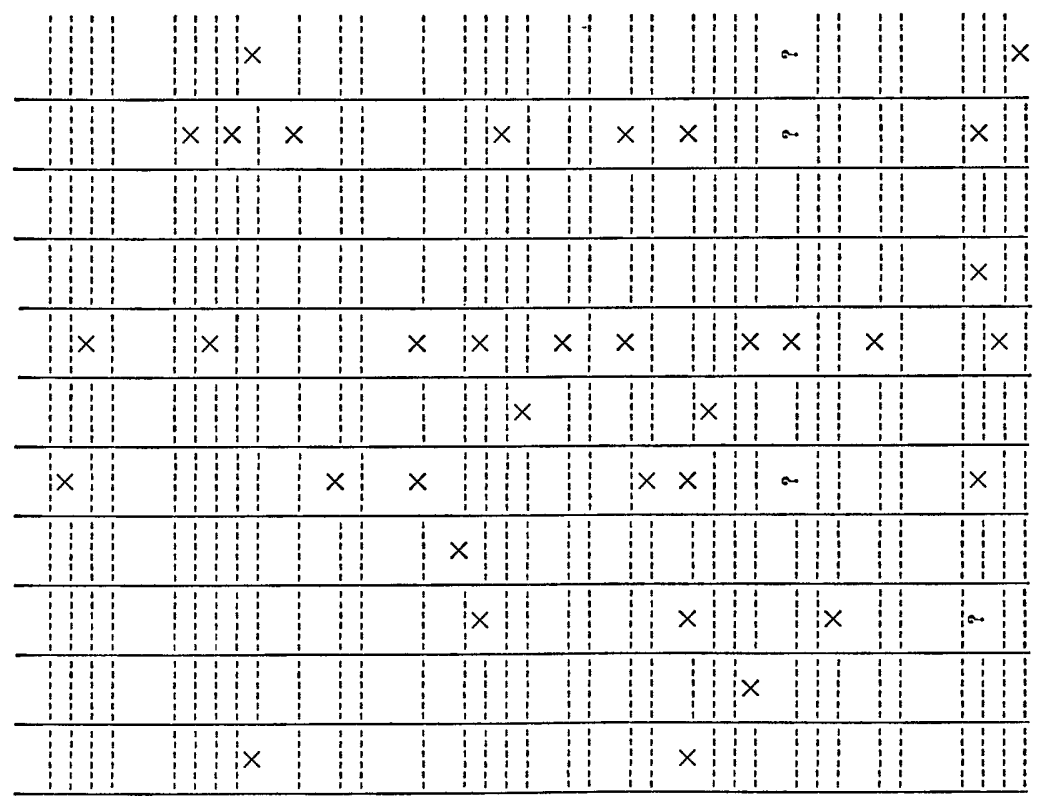

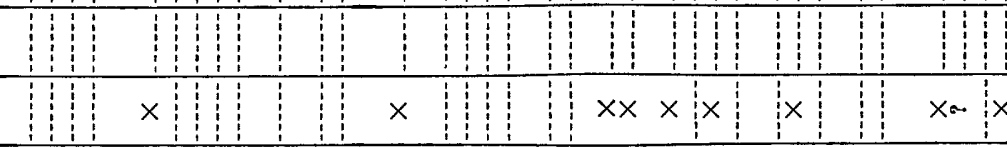

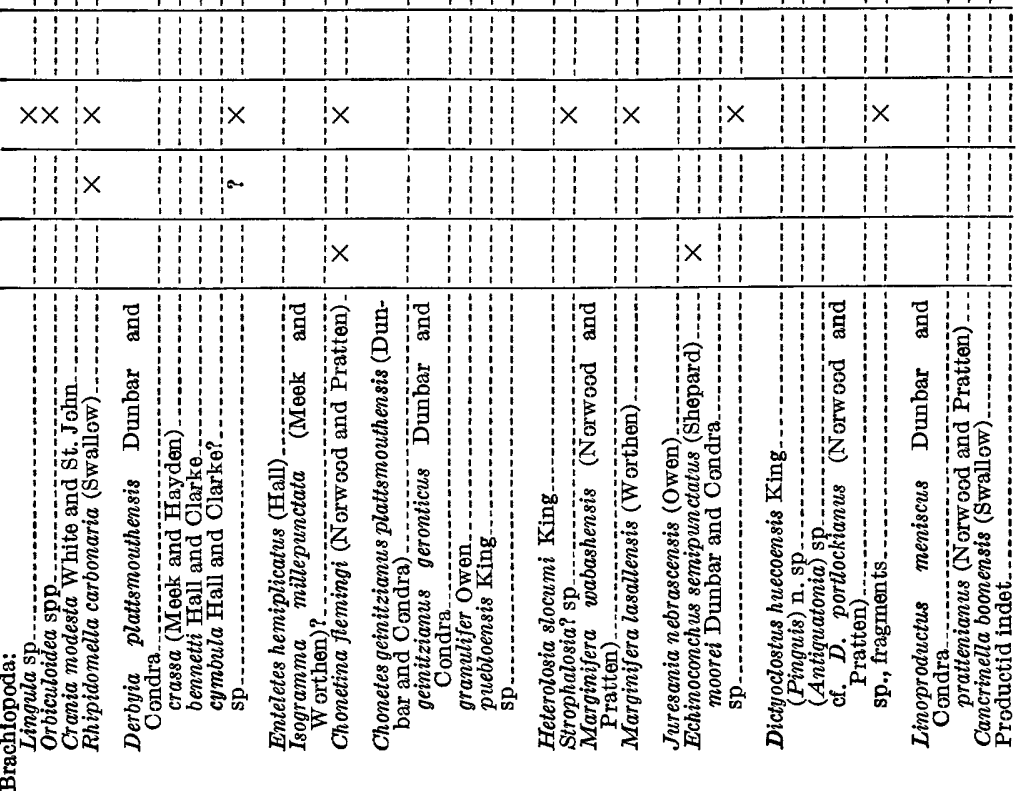




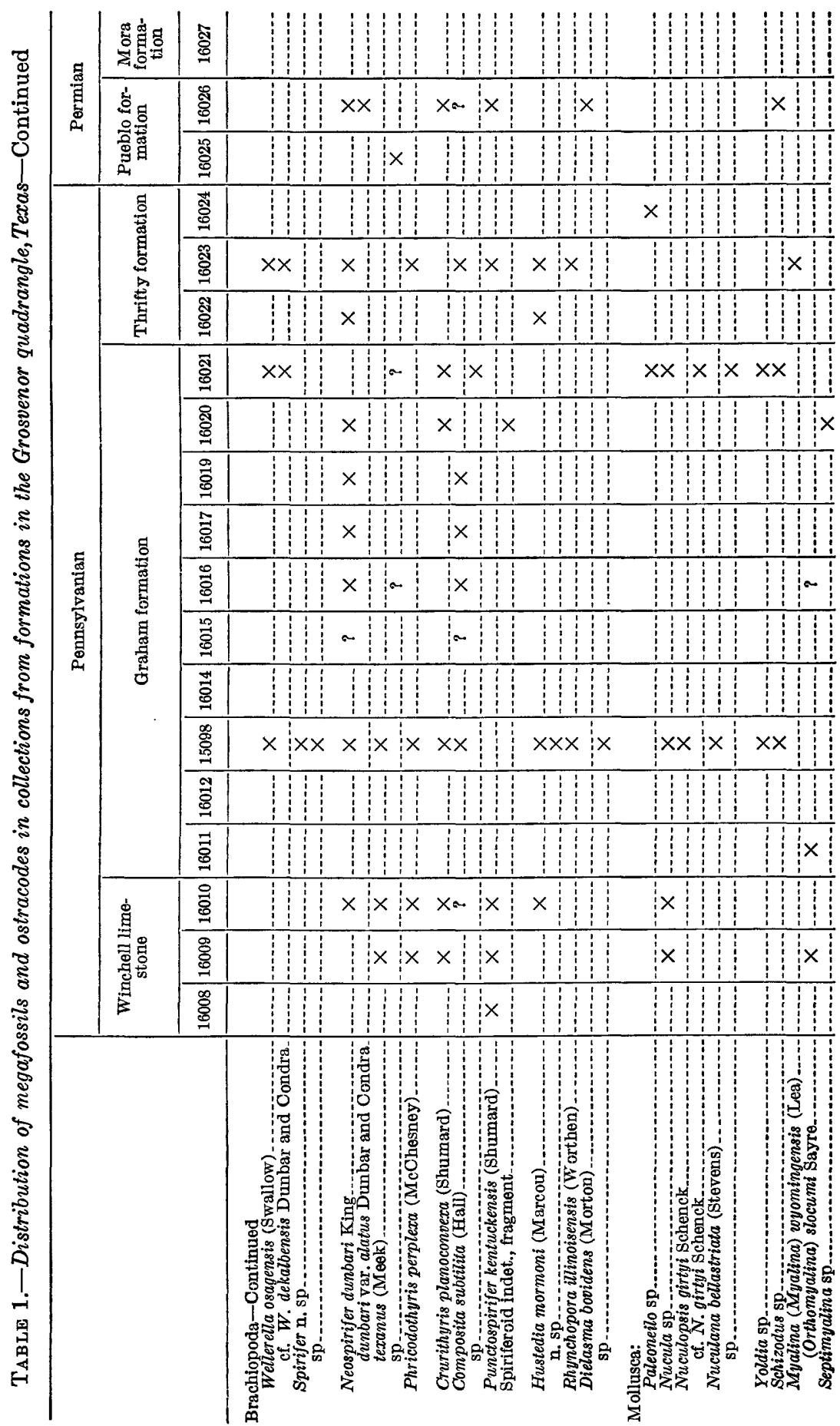




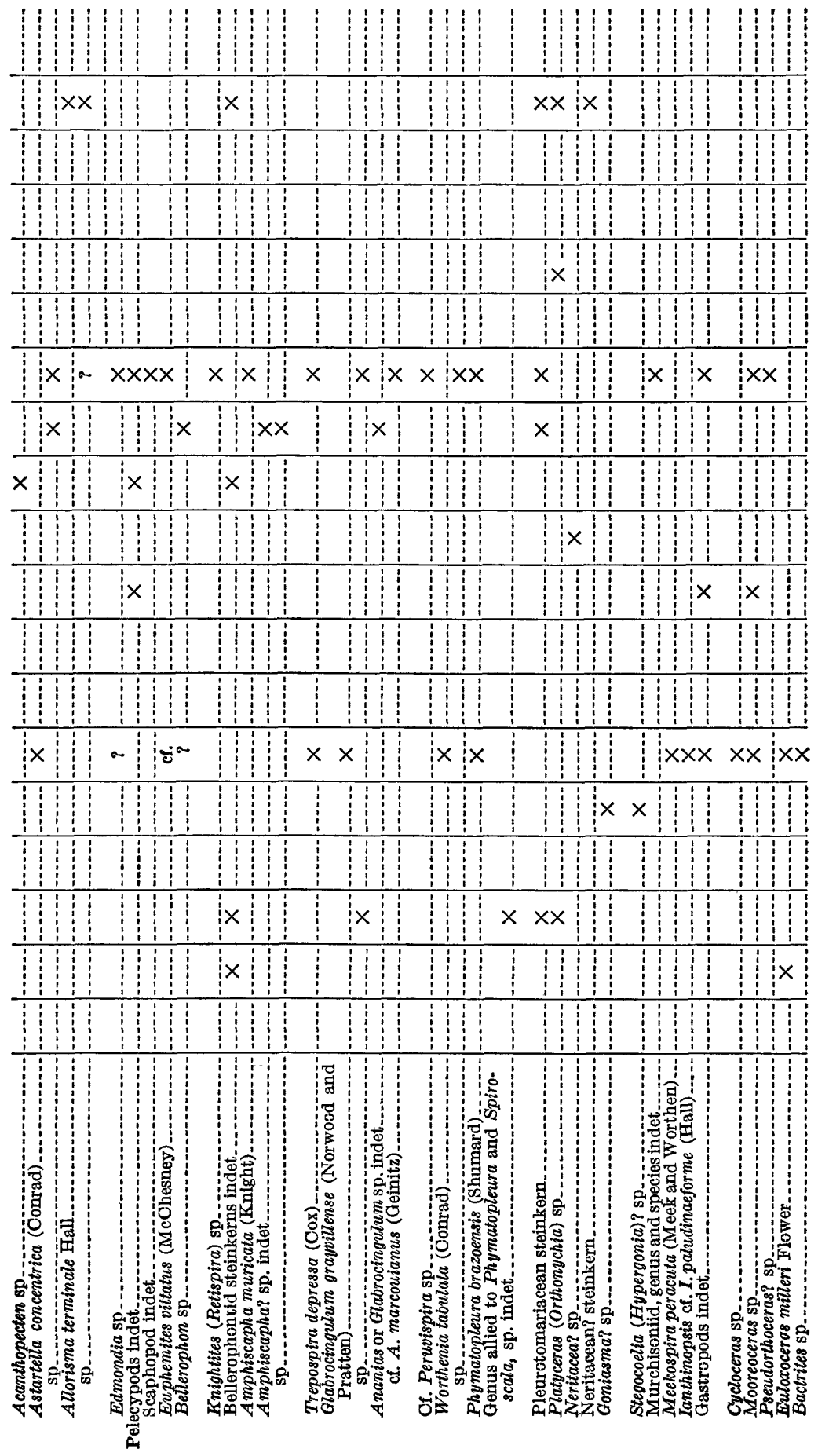




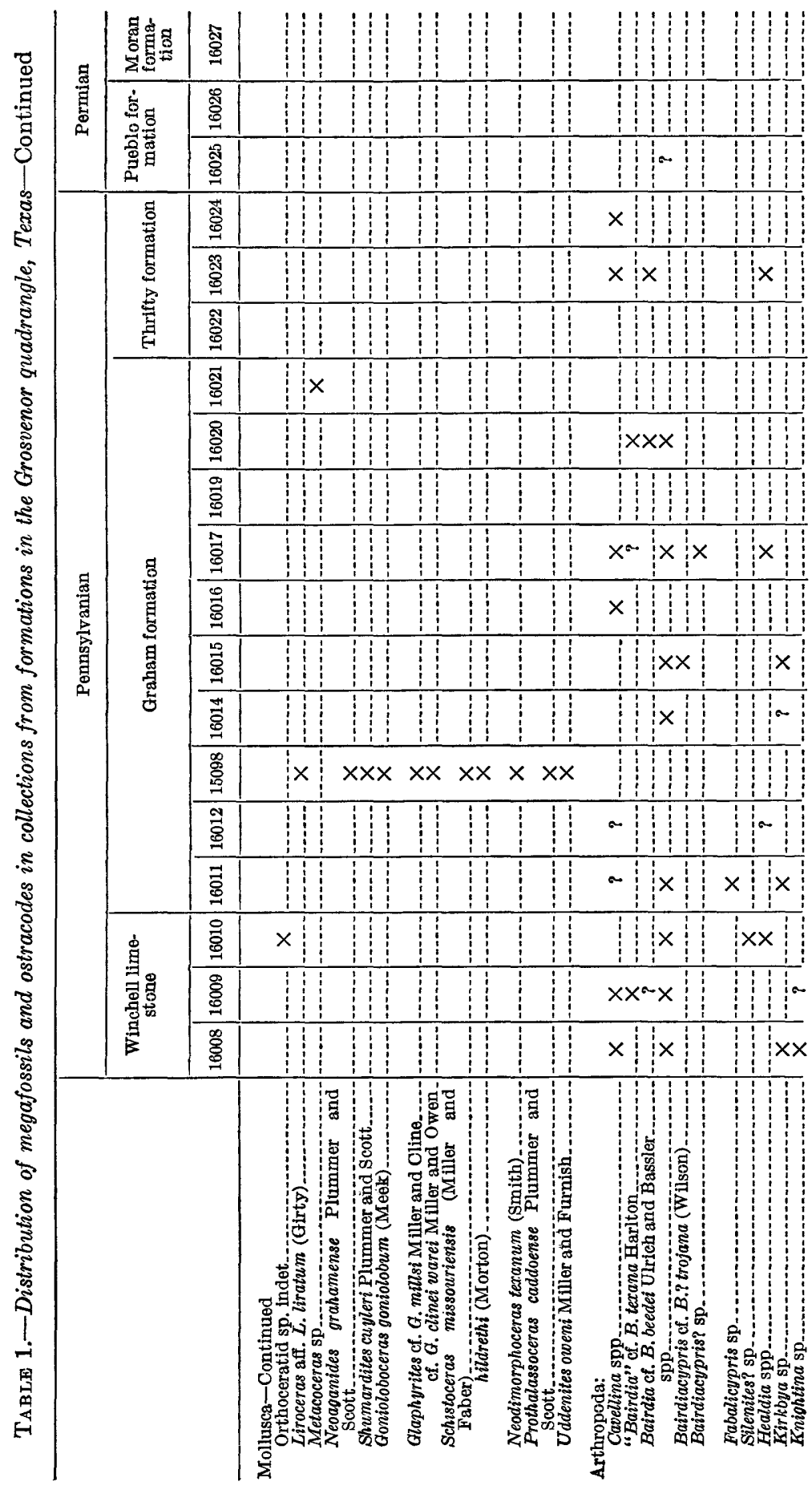




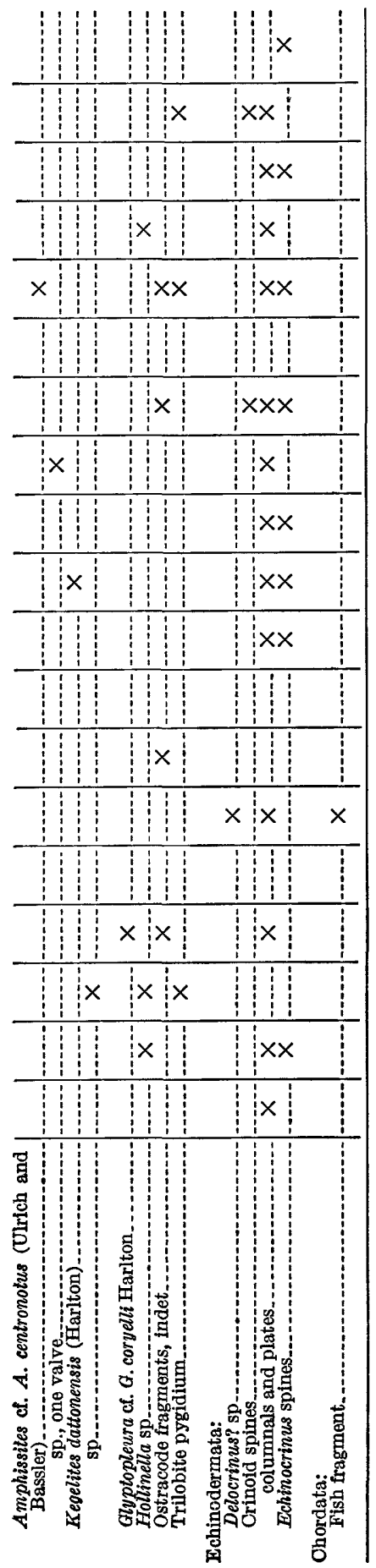


Although the Waldrip shale member contains red shale beds and discontinuous thin coal beds, suggesting emergence of the basin of deposition, the author was unable to find a disconformity. A channelfill sandstone is present locally in the lower part of the Waldrip, but it is much smaller than deposits in younger channels that cut into the Waldrip. Apparently, regional stratigraphic studies must be made before a definite conclusion can be reached on the question of an unconformity between the Pennsylvanian and Permian in central Texas.

\section{CANYON GROUP}

The Canyon group of Pennsylvanian age consists of alternating gray limestone and shale and includes smaller amounts of very fine grained to fine-grained sandstone. Of the rock types present in the quadrangle limestone is the most resistant to erosion and forms prominent, southeastward-facing cuestas. The prominence of the cuestas is accentuated by differences of vegetation; the limestone supports many small oak trees, whereas the shale is barren or covered only with grass, cactus, and mesquite.

In the nomenclature of Eargle (1960), the Canyon group contains, in ascending order, the Graford, the Winchell, the Brad, and the Caddo Creek formations. The total thickness of the Canyon group in this area, as given by Eargle, is about 620 feet. Only the upper 450 feet of the group is present in the Grosvenor quadrangle.

\section{GRAFORD FORMATION}

The Graford formation includes three members, in ascending order, the Brownwood shale, the Adams Branch limestone, and the Cedarton shale. It conformably overlies the uppermost bed of the Strawn group, the Capps limestone lentil of Plummer and Moore (1921), and is overlain by the Winchell limestone. The Graford is approximately 400 feet thick.

\section{BROWNWOOD SHALE MEMBER}

The Brownwood shale member consists mainly of silty shale but includes a small amount of very fine grained to fine-grained sandstone. At a few places impure limestone beds as much as 2 feet thick are exposed about 50 feet below the top of the member. Approximately the upper 100 feet of the Brownwood exists within the Grosvenor quadrangle. Its total thickness is about 300 feet in adjacent areas.

The shale is silty to very finely sandy, slightly fissile, and most commonly various shades of gray, although in places it is reddish purple or gray mottled with red. The sandstone is mostly thin 
bedded, lenticular, and very fine to fine grained. It is light gray and weathers light yellowish brown. Near the middle of the Brownwood shale member a conglomeratic sandstone appears to fill a shallow channel that has been cut into the underlying shale and limestone. Eargle (1960) states that this conglomeratic sandstone is at about the same stratigraphic position as the oil-producing Cross Cut sands of northern Brown County.

\section{ADAMS BRANCH LIMESTONE MEMBER}

The Adams Branch limestone member lies between the less resistant Brownwood and Cedarton shale members and forms a prominent cuesta in the extreme southeast corner of the Grosvenor quadrangle. The Adams Branch consists of 15 to 20 feet of limestone near the southern boundary of the quadrangle, but northward it grades into several thin argillaceous limestone beds separated by shale, siltstone, and sandstone.

At outcrops where the limestone is thickest, it is medium gray to light gray and distinctively thin bedded. The bedding is rather irregular and bedding planes are wavy. Fusulinids are very common, and locally brachiopods and fragments of crinoid stems are numerous.

\section{CEDARTON SHALE MEMBER}

The Cedarton shale member consists of about 80 feet of silty shale, including small amounts of sandstone and local thin beds of argillaceous limestone. The shale in the lower part of the member is gray, but upward it is mottled with red, and near the top some beds are entirely red. The sandstone beds are light gray, lenticular, very fine grained to fine grained, and in thin to medium-thick beds. The argillaceous limestone beds and parts of the shale contain a fauna of brachiopods and a few crinoid columnals.

According to Cheney (1949, p. 15) sandstone in the Cedarton shale member produces oil in the vicinity of the town of Cross Plains in southeastern Callahan County and in other areas.

\section{WINCHELL IIMESTONE}

The Winchell limestone includes about 110 feet of alternating shale and limestone. Eargle (1960) has divided the Winchell into un- named upper and lower limestone members separated by shale.

The lower limestone member, constituting approximately the basal 45 feet of the formation, consists of about one-third limestone and two-thirds shale. In areas adjacent to the Grosvenor quadrangle, the number of limestone units in the lower member ranges from two 
to five, but within the quadrangle itself the number seems to be consistently four. The limestone units become generally thicker, more resistant, darker colored, and less fossiliferous from the lowest to the highest. Brachiopods, bryozoans, and echinoderm fragments are the most numerous fossils. The uppermost bed of the lower member, about 6 feet of massive unjointed limestone, stands out prominently as a bench or secondary cuesta on the main cuesta formed by the Winchell.

The shale of the lower limestone member is of several types. In the lower part of the member, the shale is light gray mottled with purplish red and contains thin calcareous beds coated with bryozoans (colln. 16008, table 1). Brachiopods, pelecypods, and ostracodes are also preserved within the shale. The shale in the middle and upper parts of the member is medium to dark gray and contains much comminuted plant debris. The fauna is sparse and consists primarily of brachiopods.

Eargle (1960) described a channel-fill sandstone in the lower member of the Winchell limestone in the area south of the Grosvenor quadrangle. This sandstone lies below the uppermost limestone in the member and, about 5 miles southwest of the city of Brownwood, extends downward almost to the top of the Adams Branch limestone member of the Graford formation.

The upper and lower limestone members of the Winchell limestone are separated by about 35 feet of variegated greenish-gray and reddish-purple shale. The lower part of the shale contains plant fragments; other parts contain a fauna consisting mostly of bryozoans, crinoids, and brachiopods (colln. 16009, table 1).

The upper limestone member of the Winchell limestone consists of two limestone units separated by about 5 feet of fissile carbonaceous shale containing bryozoans, brachiopods, and other fossils (colln. 16010, table 1). The lower of the two limestone units is thick bedded, dark gray, microcrystalline, and about 4 feet thick. The upper limestone is about 20 feet thick, although commonly only a small part of this thickness remains atop the cuesta formed by the Winchell. It appears massive to indistinctly thick bedded where relatively unweathered, but where very highly weathered it may appear to be in medium-thick beds. Both limestone units of the upper member contain a scattered fauna of brachiopods and crinoid stems: The lower of the two contains a few fusulinids.

\section{BRAD FORMATION}

The Brad formation contains two members, the Placid shale below and the Ranger limestone above. The Placid shale member con- 
sists of about 90 feet of medium-gray and red silty shale containing a small amount of light-gray very fine grained to fine-grained sandstone. The Ranger limestone member consists of 5 to 10 feet of light olive-gray medium-thick beds of limestone locally containing fusulinids and brachiopods.

\section{CADDO CREEK FORMATION}

The topmost formation of the Canyon group is the Caddo Creek formation, which consists of the Colony Creek shale member below and the Home Creek limestone member above. The Colony Creek includes about 60 feet of gray silty shale, the upper middle part of which contains light-gray very fine grained to fine-grained sandstone. The Home Creek is a light-gray microcrystalline limestone that locally contains considerable chert, especially in the upper part. Its thickness averages about 12 feet. In relatively unweathered outcrops, it appears massive, but in much weathered outcrops it has irregular beds averaging about 3 inches thick. In general the Home Creek limestone member is only sparsely fossiliferous, but locally it contains numerous brachiopods, fusulinids, and crinoid fragments.

\section{CISCO GROUP}

The Cisco group, like the Canyon, consists of alternating limestone and shale and contains small amounts of sandstone and conglomerate in lenticular beds. In the Cisco group, however, the limestone beds are thinner, and channel-fill sandstone lenses are more numerous and larger than in the Canyon group. Because they are thinner, most of the limestone beds of the Cisco do not form prominent cuestas as do those of the Canyon.

Two formations constitute the Cisco group, in ascending order, the Graham formation and the Thrifty formation.

\section{GRAHAM FORMATION}

In the Grosvenor quadrangle, the Graham formation appears to overlie conformably the Home Creek limestone member of the Caddo Creek formation, although elsewhere in central Texas the basal contact of the formation is reported to be a disconformity marked by a deep channel (Lee, Nickell, Williams, and Henbest, 1938, p. 12-16; Cheney and Eargle, 1951b, p. 1). The top of the formation was placed by Eargle (1960) at the base of the Speck Mountain limestone member of the Thrifty formation. As thus defined, the Graham is about 300 feet thick. Five members are recognized within the formation and in ascending order are the Bluff Creek shale, Gunsight limestone, Wayland shale, Ivan limestone, and an unnamed shale member. 
The Bluff Creek shale member is composed of approximately 140 feet of gray shale that contains lenticular sandstone beds and thin limestone units. The member is approximately 100 feet thick in the southern part of the quadrangle but appears to thicken northward to about 160 feet in the northern part. The shale is poorly exposed, especially that in the lower part of the member. It is nonfissile to fissile and nonsilty to very silty; its color ranges from very light to medium gray and locally is mottled with purple or red. Most of the shale is light gray, silty, slightly fissile, and unfossiliferous, except for scattered traces of plant remains. At several localities the upper 10 to 20 feet of the shale contains many marine fossils, including fusulinids, brachiopods, gastropods, and cephalopods (colln. 15098, table 1). A sparse fauna of gastropods, pelecypods, brachiopods, crinoids, and ostracodes occurs in the lower part of the Bluff Creek at a few places (colln. 16011 and 16012, table 1).

Most sandstone beds of the Bluff Creek shale member are thin and very fine grained. Two sandstone units near the middle of the member thicken locally in such a manner as to suggest that they are channel fills.

Three thin limestone units in the Bluff Creek can be traced over a considerable part of the quadrangle. The two most persistent of these were called the North Leon and Bunger limestones by Cheney and Eargle (1951a). More recently Eargle (1960) has concluded that the correlation of these beds with the North Leon and Bunger limestone members of the Graham at their type localities in the Brazos River drainage is very questionable and that these names should not be used formally in the Colorado River drainage.

The limestone bed formerly called the North Leon is near the middle of the Bluff Creek shale member. It is most commonly a single $11 / 2$-foot bed of resistant dark-gray limestone that weathers dark yellowish orange to light brown and contains many fusulinids. Locally it may be as much as 5 feet thick, or less than a foot thick and argillaceous. Typically, it contains about 5 percent very fine quartz sand, but in some localities it is much more sandy. At some of its less typical localities the limestone is light to medium gray and weathers darker gray with little or no orange or brown limonite stain. Fusulinids are by far the most common fossils in the limestone, but locally the bed contains crinoid fragments and brachiopods. At a few exposures this limestone is immediately underlain by 2 to 4 feet of calcareous very fine grained sandstone.

The limestone formerly called Bunger lies about 30 feet above the so-called North Leon and in most respects is very similar to it. Like 
the lower bed it is a single $11 / 2$-foot bed of resistant dark-gray limestone that weathers dark yellowish brown and contains many fusulinids. However, it is much more uniform than the lower bed and maintains the same characteristics almost everywhere it is exposed. Crinoid fragments, smaller Foraminifera, and unidentified shell fragments are present in the bed at some localities.

A third, though somewhat less persistent, limestone bed lies between these two limestone beds. In the northern part of the quadrangle, this limestone is about 20 feet below the upper, or so-called Bunger limestone; but to the south the interval between the limestone beds is progressively smaller, and the two beds apparently merge south of Lake Brownwood. The bed below the so-called Bunger is 1 to 7 feet thick, averaging about $21 / 2$ feet. It is most commonly light gray but locally is dark gray and weathers to splotchy yellowish brown. At these places it may easily be confused with the limestone beds above or below it. Few fusulinids are found but many smaller Foraminifera are present, and crinoid fragments and corals occur in the bed at some places. The limestone commonly has an undulating surface and tends to weather to nodules 1 to 3 inches in diameter.

Other thin limestone beds are exposed locally near the middle of the Bluff Creek shale member. These are sandy or argillaceous and are not persistent. One bed about 20 feet below the so-called North Leon is as much as 4 feet thick and, although discontinuous, may be confused with the more persistent beds.

\section{GUNSIGHT LIMESTONE MEMBER}

The Gunsight limestone member consists of several thin limestone units separated by shale. In most parts of the quadrangle, two of these units can be mapped separately. The lower unit, which is more continuous and distinctive than the upper, is composed of light-gray microcrystalline limestone containing many horn corals and, locally, bryozoans. Fusulinids are relatively rare. The lower limestone unit of the Gunsight has an average thickness of about 4 feet and ranges in thickness from 2 to 10 feet. The differences in thickness appear to be a result of lateral transitions into calcareous shale, much of which contains many horn corals. Locally the lower unit is divided by several beds of calcareous shale.

The upper limestone unit of the Gunsight is less persistent. Because of poor exposures, the stratigraphic relationships and lateral variations of the upper unit are obscure. Apparently the limestone is absent near the northern boundary of the quadrangle. In the southern part of the quadrangle, two limestone units lie at about the position of the upper limestone unit of the Gunsight limestone mem- 
ber. The lower of these two units has been mapped as the upper unit of the Gunsight, although it may not be precisely equivalent to the upper limestone unit mapped farther north. At the most typical exposures of the upper limestone unit of the Gunsight, north and west of Lake Brownwood, the limestone is about 2 feet thick, light olive gray, and microcrystalline. This rock contains clear calcite stringers that, on microscopic examination, are found to contain remnants of algal structure. Scattered fusulinids, horn corals, and brachiopods are also present.

An interval of about 20 to 25 feet of shale, which locally contains thin limestone beds, separates the upper and lower limestone units. At some places a sparse marine fauna is present in the shale (colln. 16016 and 16017, table 1). In the area north and west of Lake Brownwood, an oolitic limestone within this interval was mapped locally. This bed is light gray and 2 to 4 feet thick.

WAYLAND SHALE MEMBER

The Wayland shale member is defined as including the beds between the Gunsight and Ivan limestone members. The top of the Wayland is undefined at localities where the Ivan limestone member is absent. The Wayland consists primarily of gray silty shale and contains discontinuous impure limestone beds a fraction of a foot thick in the lower part. The upper part of the Wayland contains siltstone and very fine grained sandstone and, in at least one exposure, dusky-red silty slightly fissile shale. At some localities the Wayland is fossiliferous; the fauna consists predominantly of brachiopods and gastropods (colln. 16019, 16020, and 16021, table 1).

Near the town of Thrifty, conglomeratic sandstone and conglomerate as much as 15 feet thick occur near the top of the Wayland. This sandstone and conglomerate appear to be a channel fill and may occupy the position of the Ivan limestone, which is absent in this area. If the sandstone and conglomerate fill a channel that has locally removed the Ivan, they are younger than the Ivan and, hence, not equivalent to the Avis sandstone member, which underlies the Ivan in the Brazos River drainage area (Nickell, 1938, p. 123, 124).

The Wayland shale member of the Grosvenor quadrangle appears to become thinner from south to north. The Ivan limestone member is absent near the southern boundary of the quadrangle, but the interval between its estimated position and the top of the Gunsight limestone member is about 140 feet. In the northern part of the quadrangle, the Wayland seems to be as thin as 65 feet. 
The Ivan limestone member is a discontinuous bed of sandy lightgray to light-olive-gray limestone. At most outcrops it is clastic and contains abraded sand- to granule-size fossil fragments. Locally it is oolitic. At several places it appears to change to calcareous sandstone along the strike and elsewhere it disappears entirely. The lack of persistence of the bed is probably due to a combination of facies changes and erosion.

UNNAMED SHALE OVERLYING THE IVAN IIMESTONE MEMBER

The beds overlying the Ivan limestone member and occupying the equivalent position where the Ivan is absent are most commonly gray to reddish-brown silty shale. Thin units of very fine grained to fine-grained standstone, some locally calcareous, are interbedded in the shale, especially at about the middle. The sandstone units are in thin- to medium-thick beds, and are light gray, and partly crossbedded. The reddish shale locally contains hematite concretions averaging about 1 inch in diameter. At some localities a coal smut or a few inches of coaly shale is in the upper 2 feet of the shale. The total thickness of the shale is 40 feet.

\section{THRIFTY FORMATION}

As defined by Eargle (1960) the Thrifty formation includes the beds between the base of the Speck Mountain limestone member and the top of the Chaffin limestone member. In the Grosvenor quadrangle it contains three limestone members - the Speck Mountain, Breckenridge, and Chaffin-separated by two unnamed shale units. The Thrifty conformably overlies the Graham formation and at most places conformably underlies the Pueblo formation. Locally the uppermost part of the Thrifty has been cut into by a channel now filled with sandstone of the Pueblo formation.

SPECK MOUNTAIN LIMESTONE MEMBER AND OVERLYING UNNAMED SHALE

The Speck Mountain limestone member is a 1- to 4 -foot bed remarkable for its persistence. Most commonly it is about 2 feet thick, medium dark gray, thick bedded, and only sparsely fossiliferous. Locally it is in thin- to medium-thick beds, and is light olive gray, and more highly fossiliferous. Fusulinids are the most common fossils; smaller Foraminifera, brachiopods, corals, and crinoid fragments are rare (colln. 16022, table 1).

The shale overlying the Speck Mountain limestone member is 25 to 35 feet thick, various shades of gray to red, and slightly silty. The upper part of this unnamed unit is fossiliferous at many out- 
crops; the fauna consists primarily of crinoid stems, bryozoans, and brachiopods but also contains a wide variety of other fossils (colln. 16023, table 1).

\section{BRECKENRIDGE LIMESTONE MEMBER AND OVERLYING UNNAMED SHALE}

The Breckenridge is a nodular limestone unit with an average thickness of about 2 feet. The maximum thickness measured in the quadrangle is 4 feet on the north side of Pecan Bayou. Thinner nodular limestone beds and layers of limestone nodules in shale occur locally above and below the main bed. The limestone is microcrystalline with tiny patches of clear, more coarsely crystalline calcite and has a fauna of fusulinids, bryozoans, brachiopods, and crinoids. Its color differs from place to place but characteristically is light greenish gray mottled with pale reddish purple.

Overlying the Breckenridge limestone member is 35 to 50 feet of gray to red silty shale, locally containing sandstone near its base. At one locality (colln. 16024, table 1) brachiopods and crinoid columnals are preserved near the middle of the shale.

A channel-fill conglomeratic sandstone is directly above the Breckenridge limestone member in many places (see fig. 2). Over part of the area the Breckenridge is missing as a result of erosion of the channel, and the lower part of the sandstone takes its place. Because the conglomeratic sandstone most commonly caps outliers, its exact stratigraphic relationships with the other sedimentary rocks are difficult to determine (fig. 3). However, on the northwest side of Indian Mountain, about 7 miles northwest of Thrifty, the Breckenridge is overlain by a sandstone-filled channel that underlies shale and the Chaffin limestone member (fig. 2). This sandstone and presumably the sandstone overlying or taking the place of the Breckenridge at other outcrops are therefore the stratigraphic equivalent of shale beds between the Breckenridge and Chaffin.
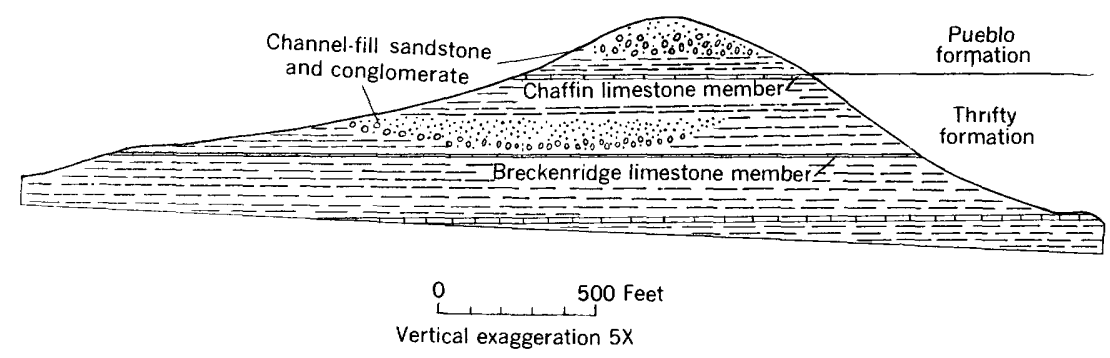

FIGURE 2.-Diagram of Indian Mountain showing stratigraphic relationships of channelfill sandstones of the upper part of the Thrifty formation and the lower part of the
Pueblo formation. 


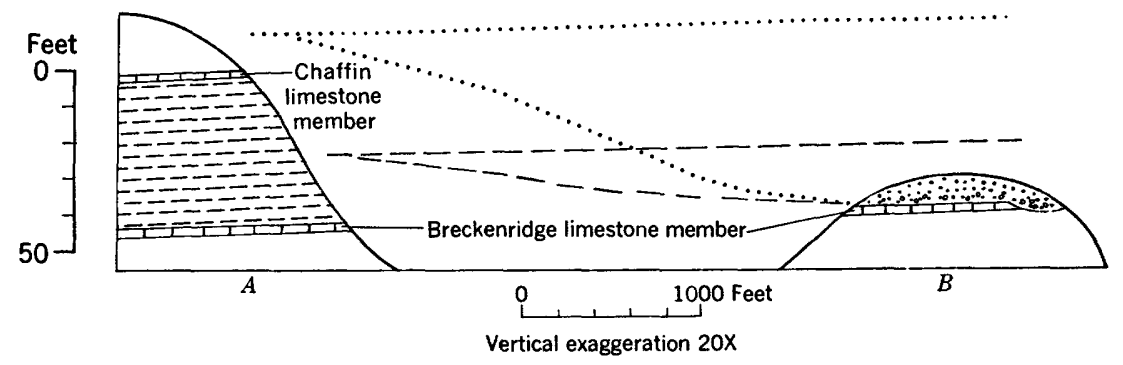

FIGURE 3.-Diagram showing typical relationships of sedimentary rocks overlying the Breckenridge limestone member of the Thrifty formation in the central part of the Grosvenor quadrangle. Dashed and dotted lines indicate two possible interpretations of the stratigraphic relations of the channel-fill sandstone exposed at $B$.

\section{CHAFFIN LIMESTONE MEMBER}

The Chaffin limestone member is a 1-foot to 3-foot unit of light gray, microcrystalline limestone. Locally it is yellowish gray or pale red, probably owing to weathering. Fusulinids and crinoid fragments are the most abundant fossils; brachiopods and corals are rare. At most places the Chaffin weathers to smooth beds, 3 to 6 inches thick.

\section{PERMIAN SYSTEM}

\section{WICHITA GROUP}

The Wichita group consists of seven formations. Only the lower two, the Pueblo and Moran, are represented in the Grosvenor quadrangle. The Wichita group in the Grosvenor quadrangle is similar lithologically to the underlying Cisco group except that it contains a larger percentage of channel-fill material and of red beds.

\section{PUEBLO FORMATION}

The base of the Pueblo formation, as defined by Eargle (1960) is at the top of the Chaffin limestone member of the Thrifty formation. The top of the Pueblo formation is the top of the Camp Colorado limestone member (Moore, 1949). Although the lowermost beds of the formation may be of Pennsylvanian age, the formation is considered to be of Permian (Wolfcamp) age for mapping purposes.

The Pueblo formation consists of gray to red shale with interbedded thin limestone and thick channel-fill sandstone. It contains in ascending order the Waldrip shale member, the Saddle Creek limestone member, the Camp Creek shale member, the Coon Mountain sandstone member, the Stockwether limestone member, the Salt Creek Bend shale member, and the Camp Colorado limestone member. 
The Waldrip shale member consists of gray to red, variegated, silty shale containing lenticular sandstone bodies and, in the upper part, thin limestone units. Its average thickness is about 100 feet. Many outcrops of the shale contain hematite nodules averaging about 1 inch in diameter, and one outcrop contains a thin gypsiferous and coaly zone. In the late 1800 's coal was mined from the Waldrip at some places along the Colorado River (Drake, 1893). Most of the sandstone is silty, argillaceous, and light gray; some is well sorted, slightly calcareous, and almost white. Cheney $(1949$, p. 11) reported that oil is produced near Cross Plains in southeastern Callahan County, from sandstone about 75 feet below the top of the member.

A 1- to 3-foot limestone unit about 10 feet below the top of the Waldrip shale member has been correlated by Eargle (1960) with the Waldrip No. 3 bed of Drake (1893). This limestone appears to be continuous in the area mapped, except where eroded away in channels now filled with the Coon Mountain sandstone member. Characteristically the limestone is clastic and contains many fusulinids and crinoid fragments. At least two other limestone units are in the Waldrip shale member, but these are discontinuous and laterally change abruptly in thickness and lithology. Fossils collected from the upper of these beds are given in table 1 (colln. 16026).

\section{SADDLE CREEK LIMESTONE MEMBER}

The Saddle Creek limestone member, about 8 feet thick, characteristically forms a prominent cuesta from which all but the lower 2 or 3 feet have been eroded. The lower $5 \frac{1}{2}$ feet of the member is mediumdark to light-gray limestone in medium-thick beds. It is most commonly finely crystalline with scattered fusulinids, crinoid fragments, brachiopods, and encrusting Foraminifera. The upper $2 \frac{1}{2}$ feet is very light gray, thin-bedded microcrystalline limestone interbedded with shale.

Over much of the northwestern part of the quadrangle the Saddle Creek has been removed by channeling, and its position is occupied by the Coon Mountain sandstone member.

\section{CAMP CREEK SHALE MEMBER}

The beds overlying the Saddle Creek limestone member and underlying the Stockwether limestone member are very poorly exposed in the Grosvenor quadrangle but can be seen about $11 / 2$ miles north of the quadrangle, 2 miles S. $65^{\circ} \mathrm{W}$. of the town of Cross Cut. These beds, known as the Camp Creek shale member, consist of about 80 feet 
of gray shale with a 1 -foot bed of very argillaceous limestone in the lower part and a 6 -foot sandstone unit in the upper part. The shale is unfossiliferous except for a few plant remains, but the argillaceous limestone contains brachiopods, bryozoans, gastropods, and pelecypods. The position of the Camp Creek shale member is occupied by the Coon Mountain sandstone member in a large part of the Grosvenor quadrangle.

\section{COON MOUNTAIN SANDSTONE MEMBER}

The Coon Mountain sandstone member was named by Drake (1893) for conglomerate and sandstone beds overlying the Camp Creek shale member and underlying the Stockwether limestone member on Coon Mountain in the Grosvenor quadrangle. On Coon Mountain the rocks consist of channel-fill conglomerate, sandstone, siltstone, and shale. These rocks do not fill an isolated channel, but a series of shallow channels cutting into each other. The complexity of the channeling can be seen in a roadcut $3 \frac{1}{2}$ miles south of Pecan Bayou and half a mile west of State Route 279 (pl. 3). At that locality, at least four separate channels can be seen. However, these seem to be local channels formed by cut and fill near the edge of a main channel. To the west, poorly exposed sandstone, siltstone, and shale, which seem almost certainly also to be channel-fill deposit, continue upward in the section almost to the base of the Camp Colorado limestone member. Apparently the sedimentary rocks on Coon Mountain fill at least three separate channels, each containing minor channels formed by local cut-and-fill (fig. 4).

The lower two of the three main channels were not mapped separately. The complexity of the rocks filling them and the scarcity of exposures make them extremely difficult to differentiate. The

W.

COON MOUNTAIN

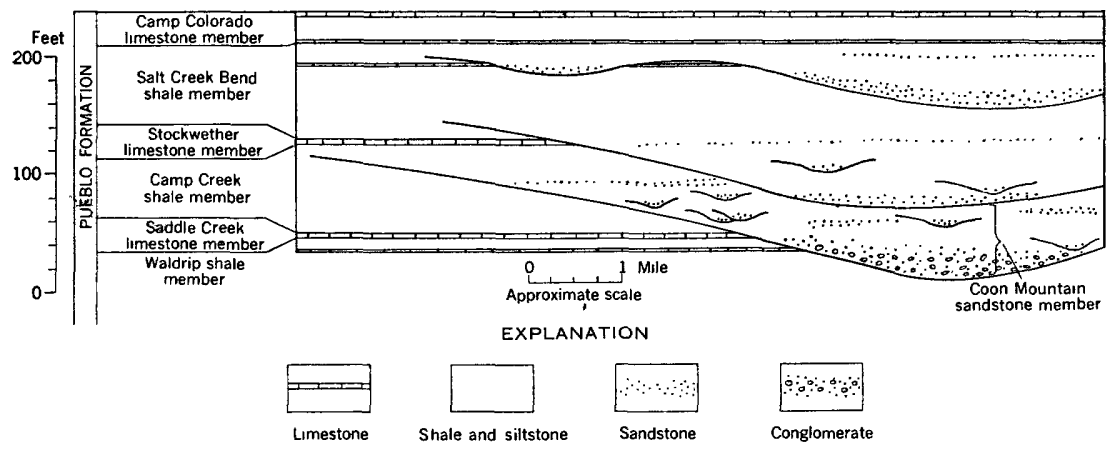

Fravam 4.-Diagram showing stratigraphic relationships of channel-fill deposits on Coon Mountain and westward. 
existence of two separate channels in that part of the section is shown southwestward from Coon Mountain by the presence of the Stockwether limestone member between them. Apparently only the lowest of the three main channel-fill deposits on Coon Mountain and westward can be considered as Drake's Coon Mountain bed, defined as underlying the Stockwether.

The uppermost channel of the three can be differentiated from the others because it overlies a thin limestone bed within the Salt Creek Bend shale member.

\section{STOCKWETHER LIMESTONE MEMBER}

The Stockwether limestone member has been removed by channel cutting over much of the quadrangle and is present only in two small areas near the northern and western boundaries of the quadrangle. In the northern part of the quadrangle, the member consists of very light gray thin-bedded to thick-bedded, cherty limestone weathering to large slabs or blocks. The average thickness is about 4 feet, but it is as much as 12 feet immediately north of the quadrangle boundary. The lower part of the member is unfossiliferous except for small fragments of material of probable algal origin. At some localities the upper part contains numerous crinoid stem fragments and bryozoans.

Along the western boundary of the quadrangle, south of the area where it has been removed by channeling, the member is poorly exposed. It seems to average about 2 feet in thickness. The lower part is microcrystalline and unfossiliferous; the upper part is very finely crystalline and contains numerous remains of crinoids, algae (?), and unidentified fossil fragments.

SAIT CREEK BEND SHALE MEMBER

The Salt Creek Bend member consists of about 75 feet of shale containing interbedded lenticular sandstone and a small amount of limestone. These beds have been eroded during three or more periods of channel cutting, and at least one was within the time interval represented by the Salt Creek Bend itself.

The shale is slightly fissile, unfossiliferous, and colored or mottled with various shades of gray, red, and grayish green. The lenticular sandstone beds have a maximum thickness of about 5 feet and are very fine grained to fine grained and gray. Some sandstone beds are calcareous and fossiliferous.

The limestone units in the Salt Creek Bend shale member are argillaceous and lenticular except for one persistent light-gray bed near the top of the member. The persistent bed is only 8 feet below 
the top of the member in the south but is as much as 30 feet below in the north. It is about 2 feet thick in most places but is as thick as 7 feet where it includes much interbedded shale. The bed contains considerable comminuted fossil debris of which only pieces of crinoid stems and a few whole brachiopods are recognizable.

Of the three periods of channel cutting recognized as affecting the Salt Creek Bend shale member, the oldest is stratigraphically below the persistent limestone bed of the upper part of the member. A second cuts into the member from about the position of its contact with the overlying Camp Colorado limestone member (fig. 5). The youngest cuts only a few feet into the Salt Creek Bend from above the Camp Colorado (fig. 6).

\section{CAMP COLORADO LIMESTONE MEMBER}

The Camp Colorado limestone member consists of two limestone units separated by shale. The lower limestone averages about 2 feet in thickness but is as much as 6 feet thick at localities where it contains interbedded shale. The basal part of the bed is microcrystalline, and the upper part clastic. It contains brachiopods, bryozoans, crinoid stem fragments, corals, and a considerable amount of comminuted fossil debris.

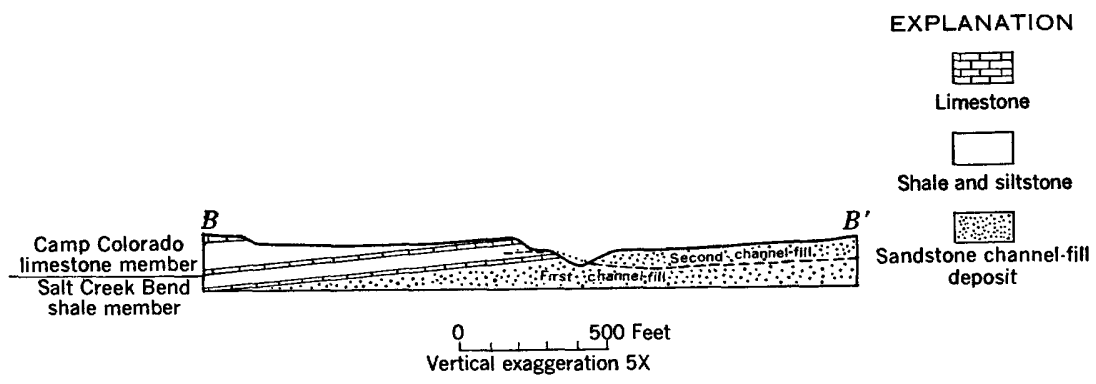

Frgure 5.-Diagram along line B-B' (pl, 1) showing stratigraphic and topographic relationships of two channel-fill deposits in the Salt Creek Bend shale member of the Pueblo formation.

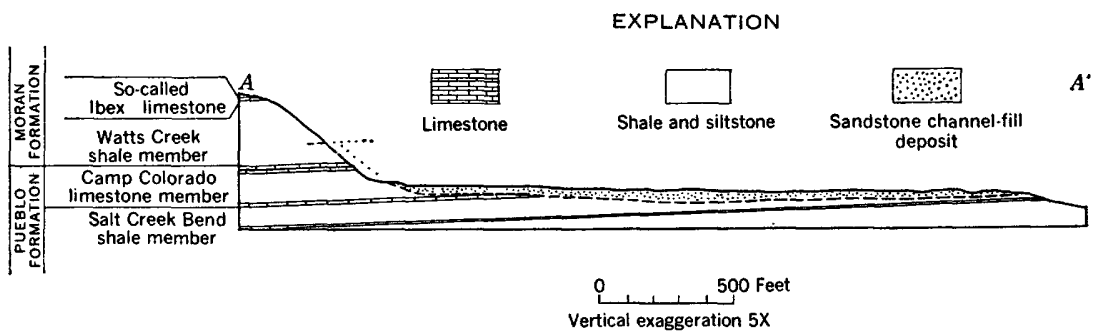

Frgurm 6.-Diagram along line $A-A^{\prime}$ (pl. 1) showing stratigraphic and topographic relationships between the Camp Colorado limestone member of the Pueblo formation and channelfill deposits in the overlying Watts Creek shale member of the Moran formation. 
The thickness of the shale above the lower limestone unit ranges from 10 to 25 feet and averages about 20 feet. The shale is gray and slightly fissile and contains bryozoans and crinoid stems. Locally it contains discontinuous argillaceous limestone beds.

The upper limestone unit is light gray and medium thick to thick bedded and, on the average, is about 9 feet thick. The thickness ranges from 5 to 10 feet and, in general, increases from south to north. At some places the limestone contains fossiliferous interbedded shale. The upper limestone unit is resistant to erosion and forms the top of a prominent escarpment. The fauna of this limestone consists of brachiopods, corals, bryozoans, fusulinids, and finely broken crinoids and other fossils.

\section{MORAN FORMATION}

The Moran formation, the topmost formation of Paleozoic age in the Grosvenor quadrangle, overlies the Pueblo formation. The Moran consists of alternating shale and limestone and contains a small amount of sandstone. Its thickness averages about 165 feet; only the lower 150 feet is present in this quadrangle.

The following members are recognized in the formation, in ascending order: the Watts Creek shale member, the Gouldbusk limestone member, the Santa Anna shale member, and the Sedwick limestone member.

\section{WATTS OREEK SHALE MEMBER}

The lowest member of the Moran formation, the Watts Creek shale member, consist of about 105 feet of shale, siltstone, and sandstone interbedded with a small amount of limestone. Sandstone and siltstone predominate in the lower half of the member in the northern half of its outcrop area in the quadrangle. Elsewhere, sandstone and siltstone occur only as thin lenticular beds in shale. The sandstone beds are gray, very fine grained to fine grained, poorly resistant to erosion, and fossiliferous. Some are calcareous. The shale beds range in color from gray to greenish gray to red; some are monocolored and some are mottled. They have poorly developed fissility. Their silt content changes from place to place. Locally bryozoans and brachiopods are preserved in the shale (colln. 16027, table 1).

At least five limestone beds have been observed within the member. The most persistent of these lies 50 to 60 feet below the top of the member and has been called the Ibex limestone by Cheney (1948). It is most commonly a single sandy, resistant bed about $1 \frac{1}{2}$ feet thick, medium gray where unweathered but stained yellowish brown with limonite where weathered. Below this limestone a channel has been eroded locally entirely through the Camp Colorado limestone member 
into the upper part of the Salt Creek Bend shale member of the Pueblo formation (pl. 2).

The other four limestone beds in the Watts Creek shale member are gray, greenish gray, and reddish gray. They are very argillaceous and nonresistant and contain a fauna of brachiopods, bryozoans, and crinoid stems. Two of them, about 5 feet and 10 feet above the Ibex limestone of Cheney, are persistent, but the others grade laterally into calcareous and fossiliferous shale.

\section{GOULDBUSK LIMESTONE MEMBER}

The Gouldbusk limestone member, 15 to 25 feet thick, is composed of a resistant basal limestone 6 feet thick overlain by an alternation of equal amounts of gray calcareous shale and argillaceous limestone. The member forms the top of an escarpment from which all but the basal limestone commonly has been removed by erosion. The basal limestone is light gray, microcrystalline, and unfossiliferous. The upper part of the member locally contains brachiopods and crinoid fragments and, near the middle, fusulinids.

\section{SANTA ANNA SHALE MEMBER}

About 20 feet of unfossiliferous, noncalcareous shale known as the Santa Anna shale member overlies the Gouldbusk limestone member. The shale is various shades of brown, red, gray, and greenish gray. Exposures of the member are poor; it is covered by soil in most places and is badly weathered elsewhere. Approximately 8 feet below the top is a single 2-foot very fine grained to fine-grained, thin-bedded sandstone containing a few marine fossils.

SEDWICK LIMESTONE MEMBER

In this area the Sedwick limestone member contains as many as three limestone beds-each 1 to 2 feet thick-separated from each other by 5 to 15 feet of shale. Only the lowest limestone bed and a few feet of the overlying shale crop out in the quadrangle. This limestone bed, about 2 feet thick, is medium gray but weathers brown. It is unfossiliferous, slightly argillaceous, and relatively nonresistant to erosion.

\section{ChanNel DePosits}

Channel-fill deposits are among the most interesting features of the Pennsylvanian and Permian rocks in this quadrangle. They have special significance because of their implications in interpreting the geologic history and paleogeography of the area, and because of their possible relationship to lenticular sandstone bodies that produce oil and gas in the nearby subsurface. 
Most of the channel-fill material is sandstone. The sandstone tends to be conglomeratic, especially in the deeper parts of the channels, and locally grades into sandy conglomerate. Many of the coarser grained and conglomeratic sandstone units are strongly crossbedded. Pebbles consit of subangular to subrounded chert; the matrix consists of subangular quartz sand. The sandstone and conglomerate are not tightly cemented on the outcrop, although they are very resistant to erosion and form the tops of a number of outliers. It is difficult to determine the stratigraphic relationships of a channel-fill deposit that caps an outlier because the deposit may represent the bottom of a channel cut down from a higher stratigraphic position. (See fig. 2.)

The sandstone and conglomerate weather to large blocks that creep considerable distances down hillsides and cover outcrops of underlying strata. It is difficult to determine the exact place where a limestone is first replaced by sandstone in a channel because of the masking effect of the sandstone float. Most of such places shown on the map are therefore located only approximately.

Siltstone and shale also fill parts of some channels. Approximately 400 feet north of an east-west road, 1 mile north of Pecan Bayou, and 0.7 mile east of State Route 279, the Chaffin limestone member of the Thrifty formation ends abruptly against channel-fill shale and siltstone. This shale and siltstone appear no different from nonchannel shale and siltstone and would not have been recognized as filling a channel if their relationship to the Chaffin was not exposed. Probably other channels contain shale and siltstone that have not been recognized as channel-fill deposits.

At least some of the channels seem to be complexes formed during several intervals of cutting and filling. Siltstone and shale of the Coon Mountain sandstone member of the Pueblo formation show complex cut and fill relationships in a road cut on the east side of Coon Mountain, half a mile west of State Route 279 and $31 / 2$ miles south of Pecan Bayou (pl. 3). Even channels that were cut in essentially one erosional interval may have been later filled by complexly interbedded conglomerate, sandstone, siltstone, and shale.

The cross-sectional shape of the channels seems worthy of special emphasis because most diagrams and cross sections greatly exaggerate the depths of the channels as compared with their width. Most of the channels were cut only a fow tens of feet stratigraphically into lower strata but have a width that is measured in hundreds of feet or even in miles.

The areal shape and extent of the channels is not clear from the study of an area the size of the Grosvenor quadrangle, although chan- 
nels shown on some parts of the map suggest a generally northeastward trend. Probably the channels had many turns and tributaries. Interpretation of the trends of channels is complicated by the effects of erosion on the distribution of channel exposures. The location of resistant channel-fill sandstone and conglomerate has affected local rates of erosion, producing outliers that in many place may mark the deepest parts of the channels. Just how much of the present shape of such outliers is due to the original distribution of channel-fill sandstone and conglomerate, and how much is fortuitous, because of modern erosion, is not apparent. Final conclusions on the distribution of the channels should be based not only on detailed surface mapping of a large part of central Texas but also on careful subsurface studies of the distribution of sandstone bodies.

The channels are considered to be stream channels rather than marine channels despite their positions between beds containing undisputed marine fossils. Several lines of evidence point to this conclusion: the cut-and-fill relationships mentioned above, the crossbedding of channel-fill sandstone, the presence in the channels of chert cobbles as large as $1 \frac{1}{2}$ inches in diameter, and the general predominance of stream-cut channels over marine channels in the geologic column. Strong marine currents might have been capable of moving the chert cobbles, but there seems to have been no adequate source of this material unless it was brought into the area by streams.

The chert fragments in the Pennsylvanian and Permian conglomerates of central Texas strongly resemble cherts in the Ouachita Mountains of Oklahoma (Bay, 1932, p. 184). The source of chert pebbles for the Texas Pennsylvanian may be a part of the Ouachita folded belt that extended through Texas east of the present outcrop of Pennsylvanian and Permian rocks.

The conclusions that the channels were cut by streams and their positions between undisputed marine strata require that the sea level rose and fell many times in relation to the level of the land. The sea floor probably was extremely flat, so that a rise or fall of sea level of only a few tens of feet might shift the shoreline many miles. Because the relative uplifts of the land were small and because the newly exposed surface was very flat, erosion was slight between the channels and little evidence of subaerial conditions was produced.

\section{CRETACEOUS SYSTEM}

The rocks of Cretaceous age in the Grosvenor quadrangle are sandstone interbedded with smaller amounts of shale and conglomerate and belong to the Trinity group. The sandstone weathers to loose 
sand that creeps down slopes and is locally moved by wind, making accurate mapping of the contact between the Cretaceous and older rocks difficult. On Coon Mountain lower Permian channel-fill deposits are in part overlain by loose sand, apparently derived largely from Cretaceous sandstone. Because there appear to be no Cretaceous deposits in place on Coon Mountain, the loose sand was not mapped as Cretaceous but was mapped with the Permian channel-fill rocks.

It is difficult to distinguish Cretaceous sandstone outliers from those formed by Pennsylvanian and Permian channel sandstones. They cannot be recognized on the basis of elevation because of relief on the unconformity at their base. One criterion that has been used for distinguishing Cretaceous sandstone from that of Pennsylvanian and Permian age is the presence of quartz pebbles in the Cretaceous rocks, whereas only chert pebbles are present in the sandstone of late Paleozoic age. Furthermore, the sand grains of many of the Cretaceous sandstone beds are more completely rounded than those of the Pennsylvanian and Permian sandstones. Where the base of a sandstone bed is exposed, the presence of caliche or of partly calichified shale or sandstone beneath it is also strongly suggestive of Cretaceous age.

\section{QUATERNARY SYSTEM}

The Quaternary strata of the quadrangle consist of alluvium along drainage and of terrace deposits. Remnants of gravel-covered terraces, several tens of feet above present stream levels, are present locally along Jim Ned Creek and Pecan Bayou. These gravel deposits resemble residual deposits of some of the Cretaceous conglomerate but can be easily recognized in most places by their high content of limestone cobbles and pebbles. The age of these deposits is unknown, but they are presumed to be Pleistocene.

Alluvium is more than 15 feet thick locally along the main drainage and has been incised to bedrock in many places. Thus the alluvium forms a low-level terrace, which, locally, can be seen to contain older terraces. Well-preserved abandoned meanders and oxbow lakes several feet above the present streams suggest that the incision is very recent. Terrace material a few feet above the general level of the main alluvium has not been differentiated.

Only the main areas of alluvium are shown on plate 1 because the primary objective of the mapping was to study the Pennsylvanian and Permian rocks of the area and because the representation on the map of small areas of alluvium obscured other contacts. 


\section{GEOLOGIC STRUCTURE}

The geologic structure in the Grosvenor quadrangle is simple. The rocks of Pennsylvanian and Permian age dip less than $1^{\circ}$ toward the northwest. The average strike and dip are about N. $25^{\circ} \mathrm{E}$. and 60 feet per mile west-northwest, respectively, but are subject to minor local variations. These variations may prove to be of importance in locating additional oil fields in the area, but the changes of dip are too small to be satisfactorily measured without the location of many additional accurate altitudes in the area. The structure of part of the northern Grosvenor quadrangle is shown by Klinger (1941) in his discussion of the Cross Cut-Blake oil-producing district, most of which is just north of the quadrangle boundary.

The Cretaceous rocks are nearly horizontal but dip slightly to the southeast. Accurate determination of the attitude of these beds has not been made because of poor exposures, the relief on the unconformity below them, and the small extent of Cretaceous outcrop in the area studied. The amount of relief on the unconformity is not known precisely, but it appears to be at least 100 feet within the quadrangle.

\section{OIL AND GAS}

Large quantities of oil and gas have been produced in the Grosvenor quadrangle. The limits of the oil and gas fields are poorly defined, and only a few of them have been given names that are recognized more than locally. The Oil and Gas Division of the Railroad Commission of Texas includes wells in Brown and Coleman Counties that are not in a recognized field under the terms "Brown County Regular Field" and "Coleman County Regular Field." According to the 1954 Annual Report of the Oil and Gas Division of the Railroad Commission (1955), the "Brown County Regular Field" produced 534,548 barrels of oil during 1954 and had a cumulative production of $35,472,733$ barrels as of January 1, 1955. Figures are not available as to the proportion produced from the Grosvenor quadrangle.

Wells have been drilled over a period of many years, but incomplete records have been kept and little subsurface information is available for many of the wells. Much of the oil production in the Grosvenor quadrangle has been from sandstone beds in the Canyon group and from the underlying Strawn group. Most wells which produce from these sandstone beds are from 1,300 to 1,700 feet deep. Oil has also been produced from sandstone beds in the Cisco group, although most of the production is from areas west and north of the quadrangle. Cheney $(1940$, p. 117), in reference to sandstone beds which produce oil from the Strawn, Canyon, and Cisco groups in Brown and Coleman Counties, reports: 
The present permeability of these "pay sands" is known to range from 100 to 850 millidarcys and porosities up to 18.5 percent or more, averaging about 250 millidarcys and 17 percent porosity as judged by relatively few core-sample determinations.

The distribution of the oil-producing sandstone beds is erratic; many producing wells are offset by wells in which shale is at the position of the reservoir sandstone. Most of the sandstone bodies appear to be channel fillings, although beach and near-shore deposits may be present in some places. Detailed subsurface work and further studies of the characteristics of channel deposits hold promise of more efficient oil exploration.

\section{DESCRIPTIONS OF LOCALITIES OF INDIVIDUAL COLLECTIONS OF FOSSILS}

Fossils were identified by Mackenzie Gordon, Jr., Helen Duncan, Ellis Yochelson, and I. G. Sohn from U.S. Geological Survey collections and are tabulated in table 1 . The localities of these collections are shown on plate 1. Descriptions of the localities of the individual collections of fossils follow.

USGS

collection No.

\section{Looality}

15098 Graham formation, Bluff Creek shale member, immediately below the lower, limestone unit of the Gunsight member; about 900 feet north of Park Road 15, 0.4 mile east of its intersection with a north-south gravel road that is about 3 miles east of State Route 279; fossils weather from shale on the north side of a low hill. Collected by M. Gordon, D. A. Myers, and R. Kopf.

16008 Winchell limestone, calcareous layers in shale between the lower two of four limestone beds in the lower limestone member; in the cut of Lake Brownwood spillway, about 200 feet east of the eastern boundary of the Grosvenor quadrangle and about 7 miles north of the city of Brownwood. Collected by D. A. Myers and R. T. Terriere.

16009 Winchell limestone, shale between the upper limestone member and the lower limestone member; on the west bank of Lake Brownwood spillway, about 7 miles due north of the city of Brownwood. Collected by P. T. Stafford.

16010 Winchell limestone, shale between the two limestone units of the upper limestone member; on the west bank of Lake Brownwood spillway. Collected by P. T. Stafford and D. H. Eargle.

16011 Graham formation, Bluff Creek shale member, shale about 10 feet below the limestone member formerly called North Leon; in the northwestern part of the Grosvenor quadrangle, 1.7 miles N. $16^{\circ} \mathrm{E}$. of Byrds, Tex., on the north and west sides of a curve in a gravel road. Collected by P. T. Stafford and R. T. Terriere.

16012 Same as 16011; collection from about 16 feet below the so-called North Leon limestone. Collected by P. T. Stafford and R. T. Terriere. 
USGS

collection No.

\section{Locality}

16014 Graham formation, lower limestone unit of the Gunsight limestone member; in the bed of Pecan Bayou where crossed by a dirt road 2.2 miles N. $32^{\circ}$ W. of Byrds, Tex. Collected by P. T. Stafford and R. T. Terriere.

16015 Graham formation, limestone near the top of the Gunsight limestone member; on the southern boundary of the Grosvenor quadrangle about 100 feet west of a north-south gravel road 5 miles west of Brownwood, Tex.; 2.2 miles due north of U.S. Highway 84 at Bangs, Tex. Collected by P. T. Stafford and R. T. Terriere.

16016 Graham formation, a 4-inch argillaceous limestone bed in shale between the upper and lower limestone units of the Gunsight limestone member; 2.5 miles N. $20^{\circ} \mathrm{W}$. of Byrds, Tex.; a low hill on the southwest side of a gravel road that parallels Pecan Bayou on the northwest side. Collected by P. T. Stafford and R. T. Terriere.

16017 Graham formation, fossils are weathering from shale between the upper and lower limestone units of the Gunsight limestone member; 1.1 miles $\mathrm{S} .45^{\circ} \mathrm{E}$. of the town of Thrifty, about 100 feet west of a gravel road at a culvert. Collected by P. T. Stafford and R. T. Terriere.

16019 Graham formation, fossils are weathering from the Wayland shale member; 0.8 mile S. $45^{\circ} \mathrm{E}$. of the town of Thrifty, near a water tank. Collected by D. H. Eargle, P. T. Stafford, and R. T. Terriere.

16020 Graham formation, thin bed of calcareous shale in the Wayland shale member; 2.2 miles $\mathrm{S} .19^{\circ} \mathrm{E}$. of the town of Thrifty, on the west side of a north-south gravel road, at and near a water tank. Collected by $P$. T. Stafford and R. T. Terriere.

16021 Graham formation, Wayland shale member; about 1,200 feet east of a north-south gravel road at a water tank, 4.7 miles $N$. $5^{\circ} \mathbf{E}$. of Byrds, Tex. Collected by P. T. Stafford and R. T. Terriere.

16022 Thrifty formation, Speck Mountain limestone member; in the bed of a creek flowing into Pecan Bayou from the north; 1.4 miles east of State Highway $279,7.2$ miles N. $22^{\circ} \mathrm{E}$. of the town of Grosvenor. Collected by P. T. Stafford and R. T. Terriere.

16023 Thrifty formation, fossils weather from shale about 10 to 25 feet above the Speck Mountain limestone member; about 300 feet north of Texas Farm to Market Road 1850, 0.9 mile east of the town of Grosvenor. Collected by P. T. Stafford and R. T. Terriere.

16024 Thrifty formation, shale 10 to 25 feet above the Breckenridge limestone member; 2.8 miles $\mathbf{S . ~} 10^{\circ} \mathrm{W}$. of the town of Grosvenor and about 400 feet southeast of Indian triangulation station. Collected by $\mathrm{P}$. T. Stafford and R. T. Terriere.

16025 Pueblo formation, Waldrip shale member, fossils are from about 1 foot of greenish-gray shale immediately overlying the Chaffin limestone member of the Thrifty formation; 2.8 miles S. $10^{\circ} \mathrm{W}$. of the town of Grosvenor and about 100 feet southeast of Indian triangulation station. Collected by P. T. Stafford and R. T. Terriere. 


\section{USGS}

collection No.

\section{Locality}

16026 Pueblo formation, 3-foot bed of argillaceous limestone in the Waldrip shale member about 25 feet below the limestone correlated with the Waldrip No. 3 bed of Drake; Cross Plains quadrangle, about 14 miles north of the northern boundary of the Grosvenor quadrangle; 0.7 mile south of the town of Cross Cut, 0.5 mile west of State Highway 279 ; road cut on the north side of an east-west gravel road. Collected by D. H. Eargle, P. T. Stafford, D. A. Myers, and R. T. Terriere.

16027 Moran formation, Watts Creek shale member, about 20 feet above the so-called Ibex limestone; about 1.3 miles $\mathrm{S}$. $35^{\circ} \mathrm{E}$. of the town of Burkett; a road cut on a nearly north-south gravel road about 0.25 mile south of its junction with a gravel road branching off to the south-southeast. Collected by P. T. Stafford.

\section{LITERATURE CITED}

Bay, H. X., 1932, A study of certain Pennsylvanian conglomerates of Texas: Texas Univ. Bull. 3201, p. 149-188.

Burnside, R. J., 1959, Geology of part of the Horseshoe atoll in Borden and Howard Counties, Texas: U. S. Geol. Survey Prof. Paper 315-B, p. 21-35.

Cheney, M. G., 1940, Geology of north-central Texas: Am. Assoc. Petroleum Geologists Bull., v. 24, p. 65-118.

(leader), 1948, Study of lower Permian and Upper Pennsylvanian rocks in Brazos and Colorado River valleys of west-central Texas, particularly from Coleman Junction to Home Creek limestones: Abilene Geol. Soc. Spring field trip, June 11-12, 1948, Abilene, Tex., 20 p.

- (chairman), 1949, Road log to Brownwood, Ranger, and Mineral Wells districts from and to Abilene with stops at type localities of important members and formations of pre-Cisco rocks, in Abilene Geol. Soc., Subsurface studies and 1949 field trip : Abilene, Tex., p. 4-25.

Cheney, M. G., and Eargle, D. H., 1951a, Geologic map of Brown County, Texas: Texas Univ., Bur. Econ. Geology map.

1951b Pennsylvanian of Brazos River and Colorado River Valleys, north-central Texas: West Texas Geol. Soc., Guidebook Spring field trip, June 1-2, 1951, Midland, Tex., $97 \mathrm{p}$.

Drake, N. F., 1893, Report on the Colorado coal field of Texas: Texas Geol. Survey, 4th Ann. Rept., pt. 1, p. 355-466. Reprinted 1917 as Texas Univ. Bull. 1755, 75 p.

Eargle, D. H., (1960), Stratigraphy of Pennsylvanian and lower Permian rocks in Brown, Coleman, and McCulloch Counties, Texas: U.S. Geol. Survey Prof. Paper 315-D.

Klinger, E. D., 1941, Cross Cut-Blake district, Brown County, Texas, in Levorsen, A. I., ed., Stratigraphic type oil fields: Am. Assoc. Petroleum Geologists, p. 548-563.

Lee, Wallace, Nickell, C. O., Williams, J. S., and Henbest, L. G., 1938, Stratigraphic and paleontologic studies of the Pennsylvanian and Permian rocks in north-central Texas: Texas Univ. Bull. 3801, $252 \mathrm{p}$.

Moore, R. C., 1949, Rocks of Permian(?) age in the Colorado River valley, north-central Texas: U.S. Geol. Survey Oil and Gas Inv. Prelim. Map 80. 
Myers. D. A., (in press), Stratigraphic ranges of some Pennsylvanian Fusulinidae from Brown and Coleman Counties, Texas: U.S. Geol. Survey Prof. Paper 315-C.

Myers, D. A., Stafford, P. T., and Burnside, R. J., 1956, Geology of the late Paleozoic Horseshoe atoll in west Texas: Texas Univ. Bull. 5607, 113 p.

Nickell, C. O., 1938, Stratigraphy of the Canyon and Cisco groups on Colorado River in Brown and Coleman Counties, Texas, in Lee, Wallace, and others, Stratigraphic and paleontologic studies of the Pennsylvanian and Permian rocks in north-central Texas: Texas Univ. Bull. 3801, p. 91-138.

Plummer, F. B., and Moore, R. C., 1921, Stratigraphy of the Pennsylvanian formations of north central Texas: Texas Univ. Bull. 2132, $237 \mathrm{p}$.

Railroad Commission of Texas, 1955, 1954 Annual report of the Oil and Gas Division: Austin, Tex.

Stafford, P. T., 1959, Geology of part of the Horseshoe atoll in Scurry and Kent Counties, Texas: U.S. Geol. Survey Prof. Paper 315-A, p. 1-20. 
